\title{
Elemental Balancing of Biomass and Medium Composition Enhances Growth Capacity in High-Density Chlorella vulgaris Cultures
}

\author{
Ramkumar K. Mandalam,* Bernhard Ø. Palsson** \\ Department of Chemical Engineering, University of Michigan, \\ Ann Arbor, Michigan 48109
}

Received 14 March 1997; accepted 2 February 1998

\begin{abstract}
The basic requirements for high-density photoautotrophic microalgal cultures in enclosed photobioreactors are a powerful light source and proper distribution of light, efficient gas exchange, and suitable medium composition. This article introduces the concept of balancing the elemental composition of growth medium with biomass composition to obtain high-density cultures. N-8 medium, commonly used for culturing Chlorella vulgaris was evaluated for its capacity to support high-density cultures on the basis of elemental stoichiometric composition of $C$. vulgaris. This analysis showed that the N-8 medium is deficient in iron, magnesium, sulfur, and nitrogen at high cell densities. N-8 medium was redesigned to contain stoichiometrically balanced quantities of the four deficient elements to support a biomass concentration of $2 \%(v / v)$. The redesigned medium, called M-8 medium, resulted in up to three- to fivefold increase in total chlorophyll content per volume of culture as compared to $\mathrm{N}-8$ medium. Further experiments showed that addition of each of the four elements separately to $\mathrm{N}-8$ medium did not improve culture performance and that balanced supplementation of all four deficient elements was required to yield the improved performance. Long-term (24 d) C. vulgaris culture in M-8 medium showed continuous increase in chlorophyll content and biomass throughout the period of cultivation. In contrast, the increase in chlorophyll content and biomass ceased after 7 and $12 \mathrm{~d}$, respectively in N-8 medium, demonstrating the higher capacity of $\mathrm{M}-8$ medium to produce biomass. Thus, the performance of high cell density photobioreactors can be significantly enhanced by proper medium design. The elemental composition of the biomass generated is an appropriate basis for medium design. (C) 1998 John Wiley \& Sons, Inc. Biotechnol Bioeng 59: 605-611, 1998.
\end{abstract}

Keywords: Chlorella vulgaris; algae; elemental balancing; medium design; high-density cultures; photoautotrophic growth

\section{INTRODUCTION}

Microalgal cultures have found application for production of oxygen for production of specialty chemicals, fuels and

\footnotetext{
* Present address: Aastrom Biosciences, Inc., P.O. Box 376, Ann Arbor, MI 48106; telephone: 313 930-5556; fax: 313 930-5520.

** Present address: Department of Bioengineering, University of California, San Diego, CA 92093-0412

Contract grant number: 10-56943
}

pharmaceuticals, industrial wastewater treatment, and life support in space (Ben-Amotz and Avron, 1989; Benemann et al., 1980; Borowitzka, 1988; Glombitza and Koch, 1989; Goldman, 1979). A variety of photobioreactor (PBR) systems (open and closed) have been used or proposed for microalgae production (Dodd, 1986; Goldman, 1979; Oswald, 1988; Terry and Raymond, 1985). Large open outdoor pond cultivation is one of the oldest industrial systems for algal cultivation for the production of single-cell protein, health food, and $\beta$-carotene (Borowitzka and Borowitzka, 1989; Soong, 1980). Closed systems have been described for the production of biomass and some specialty chemicals under axenic conditions (Ionescu et al., 1994; Juttner, 1977; Kruger and Eloff, 1978; Pirt et al., 1983). Improvements in performance of PBR systems have been obtained by optimizing illuminating techniques, efficient gas and liquid exchange units, and controlled nutrient supply (Javanmardian and Palsson, 1991b; Lee and Palsson, 1994; Lee and Bazin, 1990; Mignot et al., 1989; Miyamoto et al., 1988; Mori, 1985; Pirt et al., 1983). However, few studies focused on optimal medium formulation for high-density PBR systems have appeared.

High-density (3\% fresh weight per volume) photoautotrophic Chlorella vulgaris cultures have been obtained in specially designed photobioreactors (Javanmardian and Palsson, 1991b). Performance of frequent on-line ultrafiltration (upon reaching a biomass concentration of $0.3 \% \mathrm{v} / \mathrm{v}$ ) was necessary to obtain high cell densities. Population distributions of per cell DNA content before and after ultrafiltration revealed that the cells were blocked at some stage in the cell cycle. This blockage of cell-cycle progression led to cessation of growth and was accompanied by drop in per cell chlorophyll content (Javanmardian, 1991). Sustained oscillation in cell concentration and average per cell DNA content were observed in continuous cultures of $C$. vulgaris at low dilution rates $(0.1 / \mathrm{d})$ (Javanmardian and Palsson, 1991a). The two probable reasons for the cell-cycle modulation leading to inhibition of growth could be either the secretion of auto-inhibitory compounds or the depletion of specific nutrients in the medium. The subject of autoinhibitory compounds has been thoroughly studied, and it has been concluded that $C$. vulgaris does not secrete any such 
compounds (Mandalam and Palsson, 1995). In this study, the elemental composition and capacity of the growth medium were investigated.

Several media formulations (or "compositions") for the cultivation of microalgae have been proposed. Many of these are derived from analysis of the chemical environment in natural habitats where the algae thrive (Vonshak, 1986). There have been few media formulations based on detailed study (Provasoli and Printner, 1953) of nutrient requirements. The elements required for the growth of green algae are $\mathrm{N}, \mathrm{P}, \mathrm{K}, \mathrm{Mg}, \mathrm{Ca}, \mathrm{S}, \mathrm{Fe}, \mathrm{Cu}, \mathrm{Mn}$, and $\mathrm{Zn}$ (Oh-Hama and Miyachi, 1988). These elements are added in the form of salts, a list of which is found in Kaplan and co-workers' published work (1986). The growth of Chlorella at various concentrations of macro-nutrients and micro-nutrients have been studied (Eyster et al., 1958). There have been extensive studies on the effect of concentrations and sources of nitrogen or nitrogen to phosphorus ratio in the medium on the growth and photosynthetic rates of Chlorella (Huang et al., 1994; Jeanfils, 1993; Tam and Wong, 1996). It is also recognized that the nutrient uptake is a function of various factors such as population density, light, temperature, and pH (Kaplan et al., 1986; Rai et al., 1996). Further, the elemental composition of Chlorella changes at different stages of growth and under different conditions such as nitrogen-deficiency (Harrison et al., 1990; Oh-Hama and Miyachi, 1988). The variation in the elemental composition of $C$. vulgaris has been reported (Oh-Hama and Miyachi, 1988). Many media compositions have been suggested for culturing Chlorella (Endo et al., 1977; Endo et al., 1974; Myers, 1951; Sorokin and Krauss, 1958; Vonshak, 1986; Watanabe, 1960). The medium, N-8 (Vonshak, 1986), has been widely used for mass culturing Chlorella.

Medium composition can be formulated based on various parameters such as cellular and metabolic stoichiometry (Varma and Palsson, 1994). In this study, we have chosen elemental composition of biomass as the basis for evaluating the biomass capacity of the nutrient in a closed system.

\section{BIOMASS ELEMENTAL COMPOSITION AND STOICHIOMETRIC MEDIUM FORMULATION}

The elemental composition of Chlorella species as reported by Oh-Hama and Miyachi (1988) is shown in Table I. The source of carbon for photoautotrophic growth is carbon dioxide. It was found that sparging of $5-10 \% \mathrm{CO}_{2}$ was sufficient to obtain cell concentrations of $5 \times 10^{9}$ cells $/ \mathrm{mL}$. The elements $\mathrm{N}, \mathrm{P}, \mathrm{K}, \mathrm{Mg}, \mathrm{S}, \mathrm{Fe}, \mathrm{Ca}, \mathrm{Zn}, \mathrm{Cu}$, and $\mathrm{Mn}$ are provided by the medium.

The N-8 medium, used for culturing Chlorella consists of macro- and micro-nutrients (Vonshak, 1986) the compositions of which are given in Tables II and III. The elements were evaluated for biomass capacity based on the higher range of the values of elemental composition. The amount (g) of each element in $1 \mathrm{~L}$ of medium was calculated from the Tables II and III. The maximum biomass capacity of each element was determined by considering the amount $(\mathrm{g})$
Table I. Elemental composition of Chlorella (by weight).*

\begin{tabular}{lc}
\hline Element & \% Range \\
\hline Carbon & $51.4-72.6$ \\
Oxygen & $11.6-28.5$ \\
Hydrogen & $7.0-10.0$ \\
Nitrogen & $6.2-7.7$ \\
Phosphorus & $1.0-2.0$ \\
Potassium & $0.85-1.62$ \\
Magnesium & $0.36-0.80$ \\
Sulfur & $0.28-0.39$ \\
Iron & $0.04-0.55$ \\
Calcium & $0.005-0.08$ \\
Zinc & $0.0006-0.005$ \\
Copper & $0.001-0.004$ \\
Manganese & $0.002-0.01$ \\
\hline
\end{tabular}

*Values obtained from Oh-Hama and Miyachi (1988).

of each element in $1 \mathrm{~L}$ of medium (from Tables II and III) and the fraction of that particular element in the dry weight of cell (from Table I). The biomass capacity of each element in terms of biomass $\%(\mathrm{v} / \mathrm{v})$ for $\mathrm{N}-8$ and $\mathrm{M}-8$ medium is tabulated in Table IV. The biomass $\%(\mathrm{v} / \mathrm{v})$ is calculated as follows: Biomass $\%(\mathrm{v} / \mathrm{v})=$ (Amount of the element in unit volume of medium/fraction of dry weight of the element) $\times$ $(1 /$ dry weight fraction of cell $) \times(1 /$ density of fresh cells $) \times$ 100. The capacity in terms of cells $/ \mathrm{mL}$ can be obtained by dividing biomass by volume of each fresh cell. Dry weight of the cell was taken to be $25 \%$ of fresh weight and density of fresh cells to be $1.01 \mathrm{~g} / \mathrm{mL}$ (Myers, 1962). The average cell volume was found to be 40 femtoliters (fl).

The analysis in Table IV clearly indicates that the medium is deficient of iron, magnesium, sulfur, and nitrogen at high cell concentrations. The symptoms of cultures deficient in the four elements are well documented. In the absence of iron, retardation of growth, reduction of photosynthetic activity, and chlorophyll content is observed (Wiesnner, 1962). The cells loose chlorophyll when grown in magnesium deficient cultures (Bogorad, 1962) and cell division is blocked in sulfur-deficient cultures (Hase, 1962). Nitrogen deficiency leads to a drop in nitrogen content from $8 \%$ to $2 \%$ of dry weight and a reduction in chlorophyll content. Also, the products of photosynthesis change from protein to carbohydrate and lipid (Syrett, 1962).

Table II. Composition of macronutrients in N-8 and M-8 media.*

\begin{tabular}{lcr}
\hline \multicolumn{1}{c}{ Compound } & $\begin{array}{c}\mathrm{N}-8 \\
(\mathrm{mg} / \mathrm{L})\end{array}$ & $\begin{array}{c}\mathrm{M}-8 \\
(\mathrm{mg} / \mathrm{L})\end{array}$ \\
\hline $\mathrm{KNO}_{3}$ & 1000 & 3000 \\
$\mathrm{KH}_{2} \mathrm{PO}_{4}$ & 740 & 740 \\
$\mathrm{Na}_{2} \mathrm{HPO}_{4} \cdot 2 \mathrm{H}_{2} \mathrm{O}$ & 260 & 260 \\
$\mathrm{CaCl}_{2} \cdot 2 \mathrm{H}_{2} \mathrm{O}$ & 13 & 13 \\
$\mathrm{Fe} \mathrm{EDTA}$ & 10 & 10 \\
$\mathrm{FeSO}_{4} \cdot 7 \mathrm{H}_{2} \mathrm{O}$ & - & 130 \\
$\mathrm{MgSO}_{4} \cdot 7 \mathrm{H}_{2} \mathrm{O}$ & 50 & 400 \\
$\mathrm{Micronutrients}$ & $1 \mathrm{~mL}$ & $1 \mathrm{~mL}$ \\
\hline
\end{tabular}

*Composition of N-8 medium was obtained from Vonshak (1986). 
Table III. Composition of micronutrients in N-8 and M-8 media.*

\begin{tabular}{cc} 
Compound & $\begin{array}{c}\mathrm{N}-8 \text { \& } \mathrm{M}-8 \\
(\mathrm{~g} / \mathrm{L})\end{array}$ \\
\hline $\mathrm{Al}_{2}(\mathrm{SO} 4)_{3} \cdot 18 \mathrm{H}_{2} \mathrm{O}$ & 3.58 \\
$\mathrm{MnCl}_{2} \cdot 4 \mathrm{H}_{2} \mathrm{O}$ & 12.98 \\
$\mathrm{CuSO}_{4} \cdot 5 \mathrm{H}_{2} \mathrm{O}$ & 1.83 \\
$\mathrm{ZnSO}_{4} \cdot 7 \mathrm{H}_{2} \mathrm{O}$ & 3.2 \\
\hline
\end{tabular}

*Composition of N-8 medium was obtained form Vonshak (1986).

$\mathrm{N}-8$ medium was redesigned with the deficient nutrients with an objective to support a biomass concentration of $\sim 2 \% \mathrm{v} / \mathrm{v}\left(\sim 5 \times 10^{8}\right.$ cells $\left./ \mathrm{mL}\right)$. The amounts of $\mathrm{KNO}_{3}$ and $\mathrm{MgSO}_{4}$ were increased three- and eightfold, respectively, in the medium to support the targeted biomass concentration. The amount of iron was increased by adding $\mathrm{FeSO}_{4}(0.13$ $\mathrm{g} / \mathrm{L})$ to the medium instead of increasing the amount of FeEDTA 18 -fold (0.18 g/L). However, FeEDTA was maintained at its original concentration $(0.01 \mathrm{~g} / \mathrm{L})$ in the redesigned medium. The macro-nutrient composition of the stoichiometrically balanced medium (called M-8 medium henceforth) is shown in Table II. The amount of micronutrients were maintained the same as N-8 medium.

\section{MATERIALS \& METHODS}

\section{Cell Line and Culture Conditions}

The N-8 and M-8 media were prepared based on the composition described in Tables II and III, and sterilized using a $0.22 \mu \mathrm{m}$ (Millipore Corp., Bedford, MA) filter. The experiments were conducted in $100 \mathrm{~mL}$ spinner flasks (Bellco, Vineland, NJ) with $60 \mathrm{~mL}$ working volume. Agitation was provided by a suspended magnetic stirbar. A Multistir stirrer (Bellco, Vineland, NJ) was used to agitate the spinners at $150 \mathrm{rpm}$. Exponentially growing C. vulgaris (UTEX 398, UTEX Culture Collection of Algae, Texas), was cultivated at $5 \% \mathrm{CO}_{2}$ balanced with air at $25^{\circ} \mathrm{C}$. Each flask was illu-

Table IV. Calculated biomass capacity of N-8 and M-8 medium to generate $C$. vulgaris biomass based on its elemental composition.

\begin{tabular}{lcr} 
& \multicolumn{2}{c}{ Biomass \% (v/v) } \\
\cline { 2 - 3 } Element & N-8 medium & M-8 medium \\
\hline Nitrogen & $0.69^{*}$ & 2.08 \\
Phosphorus & 4.24 & 4.24 \\
Potassium & 14.42 & 33.49 \\
Magnesium & $0.25^{*}$ & 1.98 \\
Sulfur & $0.70^{*}$ & 6.63 \\
Iron & $0.11^{*}$ & 2.02 \\
Calcium & 1.78 & 1.78 \\
Zinc & 5.78 & 5.78 \\
Copper & 4.55 & 4.55 \\
Manganese & 14.26 & 14.26 \\
\hline
\end{tabular}

*Limiting element. minated with two circular cool white 22-W fluorescent lamps (General Electric, Inc., Cleveland, $\mathrm{OH}$ ).

Samples were collected every $24 \mathrm{~h}$. The cell number, cell volume, and chlorophyll content were monitored. The cell number and average cell volume were measured using Coulter Counter Model ZM (Coulter Electronics, Inc., Hialeah, FL). This unit includes a Coulter Channelyzer, which can measure particle size distributions. The statistical analysis of size distribution is done via a Coulter AccuComp System for the Channelyzer C256 instrument. The volumetric biomass content at any particular time point was calculated by multiplying cell count of the culture and the average cell volume at that time. The $\mathrm{pH}$ of the cultures were measured using Orion 520A pH meter (Orion Research, Inc., Boston, MA).

Longterm cultures were performed in a Bioflo II (New Brunswick Scientific, Edison, NJ), a 3 L-batch/continuous fermentor with a working volume of $2.5 \mathrm{~L}$. The culture was grown at a constant temperature of $25^{\circ} \mathrm{C}$ and illuminated by four circular cool white 40-W fluorescent lamps (a light intensity in the order of $10-15 \mathrm{~mW} / \mathrm{cm}^{2}$ at the reactor surface). The medium temperature was measured by a Resistance Temperature Detector (RTD) thermometer submerged in a thermowell. A flow rate of $100 \mathrm{~mL} / \mathrm{min}$ of $5 \% \mathrm{CO}_{2}$ supplemented with air was supplied to the Bioflo through a ring sparger, and the flowrate was controlled by the needle valve of the flowmeter. The culture was agitated at a speed of $200 \mathrm{rpm}$. The system was able to provide 1.5 times of volume of sterile air per volume of growth chamber through $0.2 \mu \mathrm{m}$ replaceable cartridge filter. The culture was sampled every $24 \mathrm{~h}$ through a hooded sampler.

Chlorophyll was extracted from samples using $100 \%$ methanol (Hitkins and Baker, 1986). The samples were diluted 10-20 times by methanol depending on the cell concentration. The vials containing the samples were wrapped with aluminum foil and stored at $4{ }^{\circ} \mathrm{C}$ for $30 \mathrm{~min}$. The samples were then centrifuged at $16,000 \mathrm{~g}$ for $10 \mathrm{~min}$. The absorbance of the green supernatant was measured at two wavelengths, 650 and $665 \mathrm{~nm}$. The chlorophyll a (mg/L), chlorophyll b (mg/L), and total chlorophyll content (mg/L) were then calculated using the equations described by Hitkins and Baker (1986).

\section{RESULTS}

\section{Effect of Medium Composition in Spinner Flask Cultures}

Cells were cultivated at low initial densities in each of the following four nutrient compositions: (1) N-8, (2) M-8 (the redesigned medium), (3) $\mathrm{N}-8$ supplemented with additional $\mathrm{KNO}_{3}$, and (4) N-8 supplemented with additional $\mathrm{MgSO}_{4} \cdot 7 \mathrm{H}_{2} \mathrm{O}$. In a second experiment, N-8, M-8, and N-8 supplemented with $\mathrm{FeSO}_{4} \cdot 7 \mathrm{H}_{2} \mathrm{O}$ were used to culture the cells. The cells used in all the flasks were obtained from stock cultures in exponential growth phase. 


\section{Cell Growth and Cell Volume}

The initial cellular growth rates (until $96 \mathrm{~h}$ ) of the four cultures were similar as shown in Figure 1a. Chlorella replicates its DNA to produce $2^{\mathrm{n}}$ daughter cells per division burst. The mature cells divide to produce 2,4 , or 8 daughter cells depending on the culture conditions (Donnan et al., 1985; Morimura, 1959; Tamiya et al., 1961; Tamiya, 1964). The increase in the average cell volume at 24, 72, and 168 $\mathrm{h}$ indicate the synchronous cell division in cultures. It appears that a percentage of cells in M-8 medium go through

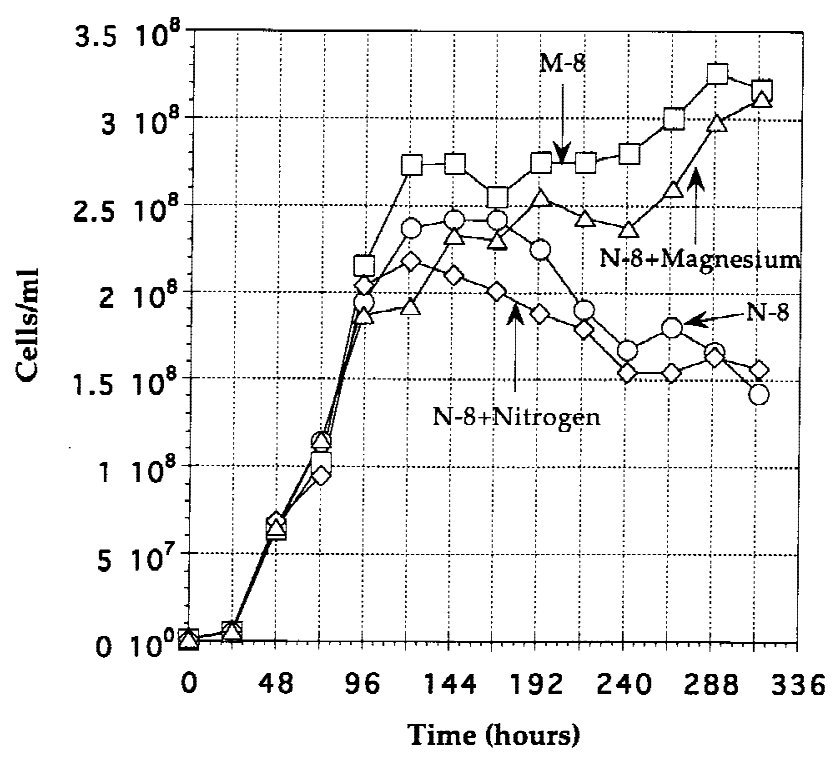

'a'

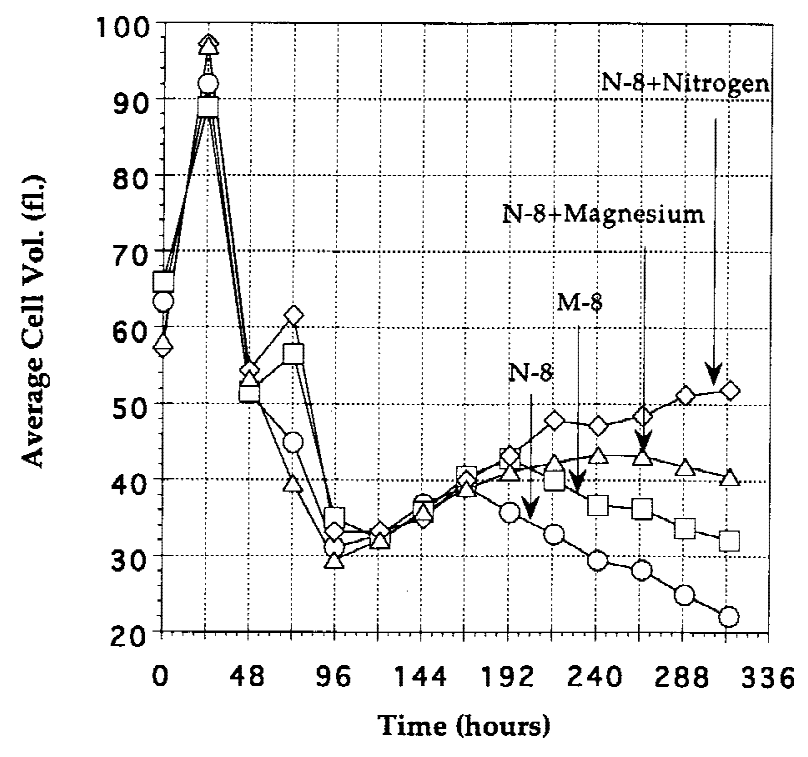

'b'

Figure 1. Growth (a) and average cell volume (b) of C. vulgaris in $\mathrm{N}-8$ medium (circle); M-8 medium (square); N-8 medium supplemented with $3.0 \mathrm{~g} / \mathrm{L} \mathrm{KNO}_{3}$ (diamond); and N-8 medium supplemented with $0.4 \mathrm{~g} / \mathrm{L}$ $\mathrm{MgSO}_{4} \cdot 7 \mathrm{H}_{2} \mathrm{O}$ (triangle). three complete rounds of replications compared to two in N-8 medium (Fig. 1). The cultures became light limited at concentrations of $1 \times 10^{7}$ cells $/ \mathrm{mL}$, beyond which a linear increase in cell number is observed. The cell number and biomass [(cell number) $\times$ (average cell volume)] profile over the period of cultivation shows lack of growth in $\mathrm{N}-8$ medium after $168 \mathrm{~h}$ (Figs. 1 and 2) indicating deficiency of nutrients. Increase in magnesium alone in the medium resulted in higher cell number, although increase in nitrogen alone did not make much difference.

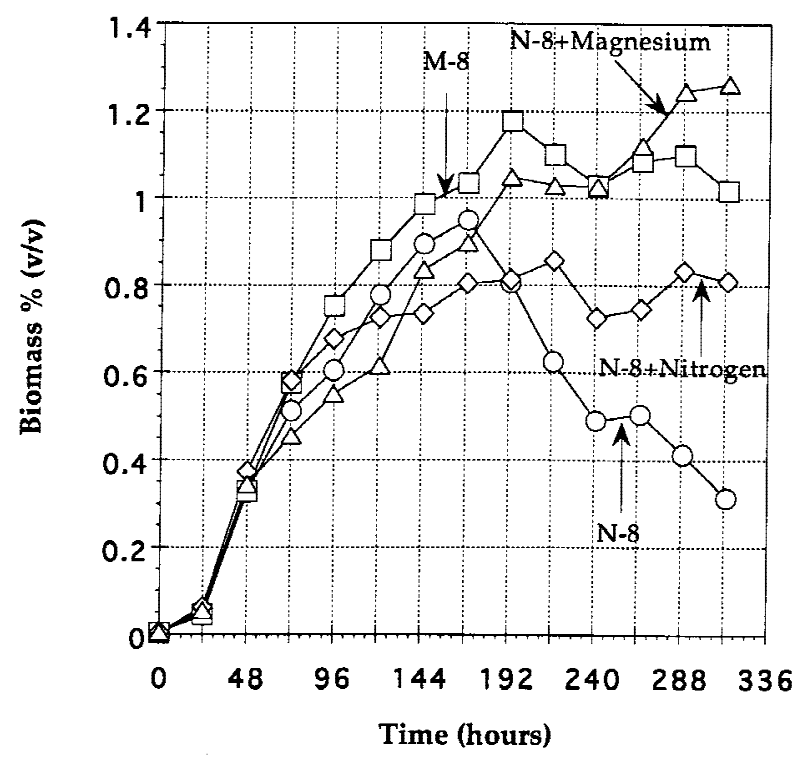

'a'

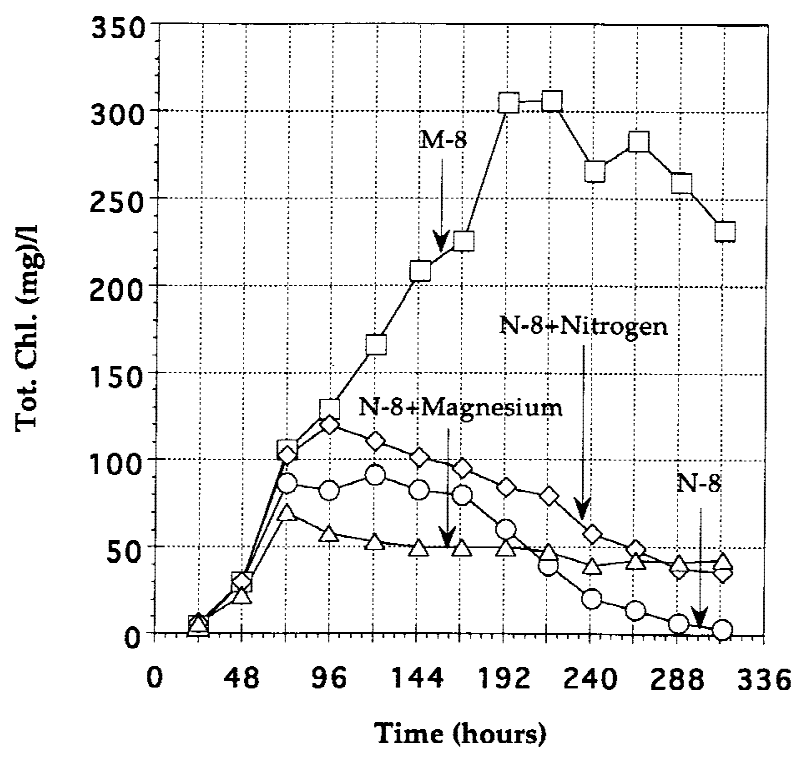

'b'

Figure 2. Biomass (a) and total chlorophyll content (b) of C. vulgaris in N-8 medium (circle); M-8 medium (square); N-8 medium supplemented with $3.0 \mathrm{~g} / \mathrm{L} \mathrm{KNO}_{3}$ (diamond); and N-8 medium supplemented with 0.4 $\mathrm{g} / \mathrm{L} \mathrm{MgSO}_{4} \cdot 7 \mathrm{H}_{2} \mathrm{O}$ (triangle). 


\section{Total Chlorophyll}

A significant difference was observed in the total chlorophyll content in M-8 medium cultures compared to other cultures (Fig. 2b). The chlorophyll content of M-8 medium culture increased continuously up to $192 \mathrm{~h}$ and was 3 times higher than the other cultures. The chlorophyll content of other cultures did not increase after $96 \mathrm{~h}$ although the biomass increased in all cultures at least up to $168 \mathrm{~h}$. Addition of nitrogen alone did not result in increase in total biomass and total chlorophyll content. Addition of magnesium resulted in increase in biomass but not in chlorophyll content. The increase in chlorophyll and biomass was observed for the same period of time in M-8 cultures.

\section{Effect of M-8 Medium in Long Term Cultures}

Chlorella vulgaris was cultivated in $3 \mathrm{~L}$ fermentors (with $2.5 \mathrm{~L}$ working volume) to study the growth capacity of the medium for long-term, large-scale cultures. Two fermentors (Bioflo) were maintained under identical conditions with cells growing in N-8 medium in one fermentor and M-8 (redesigned medium) in the other. The culture was maintained for $24 \mathrm{~d}$.

\section{Biomass and Chlorophyll Content}

The cell growth and average cell volume were measured over the period of cultivation and the biomass concentrations were calculated. The growth rate in the fermentor was slower than the flasks due to the lower light availability in the fermentors (a consequence of lower light intensity on the surface and larger diameter of the fermentor). The biomass profile showed a cessation of growth at $0.9 \% \mathrm{v} / \mathrm{v}$ in $\mathrm{N}-8$ medium culture, but a continuous increase in biomass at an uniform rate was observed in M-8 medium (Fig. 3). The constant rate of biomass production indicated that the nutrient capacity of M-8 medium was higher than N-8 medium.

The total chlorophyll content of M-8 culture was 2-3 times higher than the N-8 culture (Fig. $3 b$ ). The total chlorophyll content of cells in M-8 medium continuously increased reflecting on the enhanced capacity of the medium to maintain photoautotrophic cultures. The increase in chlorophyll content in N-8 medium ceased at $168 \mathrm{~h}$ in N-8 medium even though the biomass increase continued for another $100 \mathrm{~h}$.

\section{DISCUSSION}

With the wide range of potential industrial uses of microalgae, the need for high-density viable cultures is increasing. Significant increases in biomass productivities have been achieved in enclosed photobioreactors with the use of a powerful light source and efficient light distribution (Lee and Palsson, 1994). The benefits of a well-engineered design of a PBR can only be realized if the biological limita-
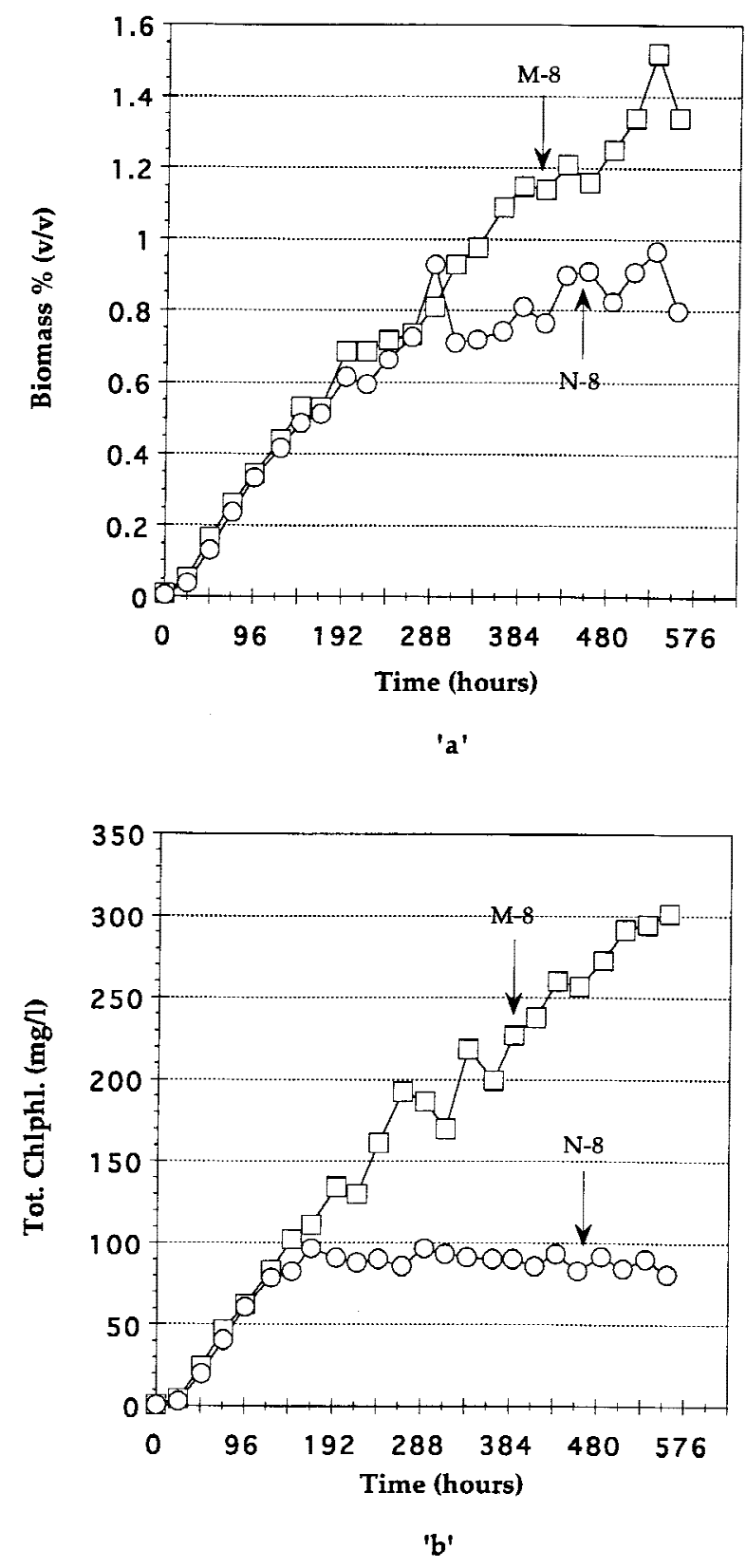

Figure 3. Biomass (a) and total chlorophyll content (b) increase in longterm C. vulgaris cultures in N-8 (circle) and M-8 (square) media.

tions (such as nutrient limitation and build-up of harmful secondary metabolites) are overcome. An earlier detailed study has shown that the organism under investigation, $C$. vulgaris, does not secrete any autoinhibitory or harmful factors at high-cell concentrations which would inhibit or retard growth (Mandalam and Palsson, 1995). The present study has demonstrated the ability of well-balanced medium to achieve high cell densities.

The analysis of N-8 medium based on the elemental composition revealed the deficiency of iron, magnesium, sulfur, and nitrogen at high cell concentrations. It appears that the $\mathrm{N}-8$ medium can support an increase in both biomass and chlorophyll content up to a cell density of $1 \times 10^{8}$ cells $/ \mathrm{mL}$ 
[0.4\% (v/v) biomass]. The blockage of cell cycle and temporary loss of chlorophyll observed at high cell densities in an earlier study (Javanmardian and Palsson, 1991) can be attributed to the deprivation of the elements mentioned above.

This study has used the simple cellular elemental composition as the basis for redesigning algal growth media. It is often assumed that the limiting nutrients are nitrogen and phosphorus (elements that comprise higher percentages in the cellular composition), and the other elements are always in excess in the medium. Therefore, it has been recommended that addition of the major elements can increase the overall capacity of the medium. It was observed in this study that addition of nitrogen to N-8 medium did not significantly result in an increase in biomass or chlorophyll. However, addition of magnesium to N-8 medium resulted in an increase in biomass content and not chlorophyll content. This result was interesting in the light that cells need magnesium to synthesize chlorophyll. It has been reported that in $C$. vulgaris cultures, as nitrogen deficiency develops, the amount of chlorophyll in the cells decreases faster than the nitrogen content, and the accumulation of carbohydrate starts much earlier than fat (Syrett, 1962). Although the exact changes in biomass composition are not known, it is likely that the increase in biomass and decrease in chlorophyll content (in N-8 medium cultures supplemented with $\mathrm{Mg}$ ) is an outcome of this process. Thus, the results from this study clearly indicated that the addition of one of the major deficient elements to N-8 medium is not sufficient to support balanced photoautotrophic growth. The synergistic effect of the elements in addition to the components of $\mathrm{N}-8$ medium showed the enhanced performance (increase in both biomass and chlorophyll content), thus emphasizing the importance of a balanced medium.

The continuous increase in biomass and chlorophyll content in large-scale, long-term M-8 medium photoautotrophic cultures has demonstrated the enhanced capacity of the medium to support high-density cultures. High-density cultures can be achieved in photobioreactors with minimal, or even without any, change of medium or perfusion. The growth rate is influenced by light intensity and delivery as the penetration depth of light decreases with increase in cell concentration. M-8 medium has the capacity of increasing the growth rate, biomass and chlorophyll productivity significantly in the presence of a powerful light source and uniform light delivery. The enhanced chlorophyll content could potentially result in increased oxygen production as each mole of chlorophyll produces 50-400 mol of oxygen per hour (Myers and Graham, 1971). This study has underlined the significance of medium development in achieving highdensity cultures.

\section{References}

Ben-Amotz, A., Avron, M. 1989. The biotechnology of mass culturing Dunaliella for products of commercial interest. pp. 91-114. In: R. C. Cresswell, T. A. V. Rees, and H. Shah (eds.), Algal and cyanobacterial biotechnology. Longman Scientific \& Technical, New York.
Benemann, J. R., Koopman, B. L., Weissman, J. C., Esienberg, D. E., Goebel, R. P. 1980. Development of microalgae waste water treatment and harvesting technologies in California, pp. 457-496. In: G. Shelef and C. Soeder (eds.), Algal biomass. Elsevier Biomedical Press, Amsterdam.

Bogorad, L. 1962. Chlorophylls, pp. 385-408. In: R. A. Lewin (ed.), Physiology and biochemistry of algae. Academic Press, New York.

Borowitzka, L. J., Borowitzka, M. A. 1989. Industrial production: Methods and economics, pp. 294-316. In: R. C. Cresswell, T. A. V. Rees, and H. Shah (eds.), Algal and cyanobacterial biotechnology. Longman Scientific \& Technical, New York.

Borowitzka, M. A. 1988. Vitamins and fine chemicals from micro-algae, pp. 153-196. In: M. A. Borowitzka and L. J. Borowitzka (eds.), Microalgal biotechnology. Cambridge University Press, Cambridge.

Dodd, J. C. 1986. Elements of pond design and construction, pp. 265-283. In: A. Richmond (ed.), Handbook of microalgal mass culture. CRC Press, Boca Raton, FL.

Donnan, L., Carvill, E. P., John, P. C. L. 1985. The cell cycles of Chlamydomonas and Chlorella. New Phytology 99: 1-40.

Endo, H., Hosaya, H., Koibuchi, T. 1977. Growth yields of Chlorella regulgaris in dark-heterotrophic continuous culture using acetate. $J$. Ferment. Technol. 55: 369-379.

Endo, H., Nakajima, K., Chino, R., Shirota, M. 1974. Growth characteristics and cellular components of Chlorella regularis, heterotrophic fast growing strain. Agricul. Biol. Chem. 38: 9-18.

Eyster, H. C., Brown, T. E., Tanner, H. A. 1958. Mineral requirements for Chlorella Pyrenoidosa under autotrophic and heterotrophic conditions, pp. 157-191. In: C. A. Lamb, O. J. Bentley, and J. M. Beattie (eds.), Trace elements. Academic Press, New York.

Glombitza, K.-W., Koch, M. 1989. Secondary metabolites of pharmaceutical potential, pp. 161-219. In: R. C. Cresswell, T. A. V. Rees, and H. Shah (eds.), Algal and cyanobacterial biotechnology. Longman Scientific \& Technical, New York.

Goldman, J. C. 1979. Outdoor algal mass cultures: (ii) Photosynthetic yield limitations. Wat. Res. 13: 119-136.

Harrison, P. J., Thompson, P. A., Calderwood, G. S. 1990. Effect of nutrient and light limitation on the biochemical composition of phytoplankton. J. Appl. Phycol. 2: 45-56.

Hase, E. 1962. Cell division, pp. 617-624. In: R. A. Lewin (ed.), Physiology and biochemistry of algae. Academic Press, New York.

Hitkins, M. F., Baker, N. R. 1986. Photosynthesis: Energy transduction. IRL Press, UK.

Huang, B., Hong, H., Chen, L. 1994. The physiological effects of different N-P ratios on algae in semicontinuous culture. Asian Mar. Biol. 11: 137-142.

Ionescu, A., Stanca, D., Vladimirescu, A. 1994. The growth of some green algae (Scenedesmus, Chlorella, Botryococcus, Ulva): Physiology and biochemistry. Biologia 49: 605-610.

Javanmardian, M., Palsson, B. O. 1991a. Continuous photoautotrophic cultures of the eukaryotic alga Chlorella vugaris can exhibit stable oscillatory dynamics. Biotechnol. Bioeng. 39: 487-497.

Javanmardian, M., Palsson, B. O. 1991b. High-density photoautotrophic algal cultures: Design, construction, and operation of a novel photobioreactor system. Biotechnol. Bioeng. 38: 1182-1189.

Javanmardian, M. 1991. High density algal cultures: Photobioreactor design and cell cycle kinetics. Ph.D. thesis, University of Michigan, Ann Arbor, MI.

Jeanfils, J., Canisius, M. F., Burlion, N. 1993. Effect of high nitrate concentrations on growth and nitrate uptake by free-living and immobilized Chlorella vulgaris cells. J. Appl. Phycol. 5: 369-374.

Juttner, F. 1977. Thirty liter tower-type pilot plant for the mass cultivation of light and motion sensitive planktonic algae. Biotechnol. Bioeng. 19: 1679-1688.

Kaplan, D., Richmond, A. E., Dubinsky, Z., Aaronson, S. 1986. Algal nutrition, pp. 147-198. In: A. Richmond (ed.), Handbook of microalgal mass culture. CRC Press, Boca Raton, FL.

Kruger, C. H. J., Eloff, J. N. 1978. Mass culture of Microcystis under sterile conditions. J. Limnol. Soc. S. Sfr. 4: 119-124. 
Lee, C.-G., Palsson, B. O. 1994. High-density algal photobioreactors using light-emitting diodes. Biotechnol. Bioeng. 44: 1161-1167.

Lee, E. T.-Y., Bazin, M. J. 1990. A laboratory scale air-lift helical photobioreactor to increase biomass output rate of photosynthetic algal cultures. New Phytology 116: 331-335.

Mandalam, R., Palsson, B. O. 1995. Chlorella vulgaris (Chlorellaceae) does not secrete autoinhibitors at high cell densities. Amer. J. Botany 82: 955-963.

Mignot, L., Junter, G. A., Labbe, M. 1989. A new type of immobilized-cell photobioreactor with internal illumination by optical fibers. Biotechnol. Techn. 3: 299-304.

Miyamoto, K., Wable, O., Benemann, J. R. 1988. Vertical tubular reactor for microalgae cultivation. Biotechnol. Lett. 10: 703-708.

Mori, K. 1985. Photoautotrophic bioreactor using solar rays condensed by fresnal lenses. Symposium on Biotechnology for Fuels and Chemicals, 7: 331-345. Wiley, New York, NY.

Morimura, Y. 1959. Synchronous cultures of Chlorella, kinetic analysis of the life cycle of Chlorella ellipsoidea as affected by changes of temperature and light intensity. Plant Cell Physiol. 1: 49-62.

Myers, J. 1951. On the mass culture of algae. Plant Physiol. 26: 539-548.

Myers, J. 1962. Laboratory cultures, pp. 603-615. In: R. A. Lewin (ed.), Physiology and biochemistry of algae. Academic Press, New York.

Myers, J., Graham, J. 1971. The photosynthetic unit in Chlorella. Plant Physiol. 48: 282-286.

Oh-Hama, T., Miyachi, S. 1988. Chlorella, pp. 3-26. In M. A. Borowitzka and L. J. Borowitzka (eds.), Microalgal biotechnology. Cambridge University Press, Cambridge.

Oswald, W. J. 1988. Large-scale algal culture systems (engineering aspects), pp. 3-26. In: M. A. Borowitzka and L. J. Borowitzka (eds.), Microalgal biotechnology. Cambridge University Press, Cambridge.

Pirt, S. J., Lee, Y. K., Walach, M. R., Bayuzi, H. H. M., Bazin, M. J. 1983. A tubular photobioreactor for photosynthetic production of biomass from $\mathrm{CO}_{2}$ : Design and performance. J. Chem. Technol. Biotechnol. 33b: $35-38$.
Provasoli, L., Printner, I. J. 1953. Ecological implication of in vivo nutritional requirements of algae flagellate. Ann. N.Y. Acad. Sci. 56: 839.

Rai, L. C., Rai, P. K., Mallick, N. 1996. Regulation of heavy metal toxicity in acid-tolerant Chlorella: Physiological and biochemical approaches. Environ. Exp. Botany 36: 99-109.

Soong, P. 1980. Production and development of Chlorella and Spirulina in Taiwan, pp. 97-113. In: G. Shelef and C. J. Soeder (eds.), Algae biomass. Elsevier Biomedical Press, Amsterdam.

Sorokin, C., Krauss, R. W. 1958. The effect of light intensity on the growth rates of green algae. Plant Physiol. 33: 109-113.

Syrett, P. J. 1962. Nitrogen assimilation, pp. 171-188. In: R. A. Lewin (ed.), Physiology and biochemistry of algae. Academic Press, New York.

Tam, N. F. Y., Wong, Y. S. 1996. Effect of ammonia concentrations on growth of Chlorella vulgaris and nitrogen removal from media. Bioresource Technol. 57: 45-50.

Tamiya, H., Morimora, Y., Yokota, M., Kunieda, R. 1961. Mode of nuclear division in synchronous culture of Chlorella: Comparison of various methods of synchronization. Plant Cell Physiol. 2: 383-403.

Tamiya, H. 1964. Growth and cell division of Chlorella, pp. 247-305. In: E. Zeuthen (ed.), Synchrony in cell division and growth. Wiley Interscience, New York.

Terry, K. L., Raymond, L. P. 1985. System design for the autotrophic production of microalgae. Enz. Microbial. Technol. 7: 474-487.

Varma, A., Palsson, B. O. 1994. Metabolic flux balancing: Basic concepts, scientific and practical use. Bio/Technol. 12: 994-998.

Vonshak, A. 1986. Laboratory techniques for the cultivation of microalgae, pp. 117-145. In: A. Richmond (ed.), Handbook of microalgal mass culture. CRC Press, Boca Raton, FL.

Watanabe, A. 1960. List of algal strains in collection at the Institute of Applied Microbiology. J. Gen. Appl. Microbiol. 6: 283-292.

Wiesnner, W. 1962. Inorganic micronutrients, pp. 267-286. In: R. A. Lewin (ed.), Physiology and biochemistry of algae. Academic Press, New York. 